\title{
Community-based Security and Justice: Arbakai in Afghanistan
}

\section{Mohammad Osman Tariq}

Abstract This article discusses the successful bottom-up justice and security institutions in south-east Afghanistan that are delivering justice and security to the people in a complex atmosphere characterised by a weak and contested state, high levels of corruption, massive international and regional intervention, internal conflict based on ideology and ethnicity, and exclusion of one ethnic group and overrepresentation of others in the political arena. These local-level institutions are called Jirga and Arbakai. They have their own conceptual and contextual principles, which differentiate the Arbakai from private security companies, militias, or warlord-related armed groups. In effect, the Arbakai serves as an alternative system to the state security sector, delivering physical security to individual members of a tribe and community.

\section{Introduction}

Globally, there is a wide range of efforts to promote citizens' participation in their own security. Achieving such an objective may seem challenging but several communities have been involved in taking on responsibilities traditionally related to the police systems and state. The obstacle confronting this approach is often pessimism of the citizenry regarding a top-down strategy, which makes it difficult for citizens to acquire ownership of security policies. However, there exist grassroots security and justice institutions that comprise a part of informal local governance which are more active, accountable, just and reliable for their people. Examples can be found in Afghanistan's south-east region (Loya Paktia) and are known as Jirga and Arbakai. This article will discuss the general structure of these two informal governance institutions: Jirga is a governing and judicial body at the community level and Arbakai is a law enforcement body implementing decisions made by the Jirga.

\section{The current situation}

At the time of writing, Afghanistan is a country facing acute violence with domestic and international dimensions, despite many efforts by donors and the national government to strengthen and reform its formal security and justice institutions. Analysts seem to agree on four main reasons for the failure of these 'reformed' institutions to secure the country:

The first concerns the exclusion of Pashtuns, the country's largest ethnic group from the political arena and state security sector, which are instead dominated by a small sub-tribe from a minority ethnic group (the Panjshiris) under a weak state led by foreign-backed leadership (Giustozzi 2007). In contrast to what is happening in Iraq, in Afghanistan the legal support of the international community is directed towards a minority and the major ethnic group has few political rights and little legal support. This imbalance is explored in different analyses and reports (Sedra 2004; ICG 2007). ${ }^{1}$

The second reason is widespread corruption within the security sector and its various subsectors, part of a general illness in the government that undermines legitimacy of the state 'institutions' in the 'eyes of Afghans' (ICG 2007: 14). A recently published International Crisis Group (ICG) report documents the Afghan public's lack of confidence in the police forces and views them as a source of failure. ${ }^{2}$ Corruption is not only limited to state institutions, but also is a general problem in the distribution of aid from donor agencies: up to 50 per cent of aid budgets are lost to corruption, 
fuelling dangerous public resentment that has left 'up to 60 per cent' of the population feeling dissatisfied (Beaumont 2007).

The third reason involves the drug economy and the distribution of the proceeds across borders between warring parties, including state officials (especially those from security institutions), drug traders and insurgents. Key government positions in the area of counter-narcotics are sold by senior level officials, and often the people hired are obliged, based upon personal contracts, to pay monthly or annual fees (ICG 2007).

The fourth reason is the presence of international forces that comprise part of the problem, rather than part of the solution (Luckham 2004; Sedra 2004: 6). These forces have caused an increased number of civilian casualties. The newly elected president of the USA said in his election campaign that he will increase troops in Afghanistan. The increased number of troops despatched by the USSR in the 1980s only gave more popularity to Mujahideen and did not have a successful outcome for the occupiers.

The history of the country shows that Afghans will never accept foreign presence in their territory and will react by taking action against the occupiers. Due to increased US airstrikes near social gathering places and irresponsible military performance, there have been several recent incidents with, for example, 275 civilian casualties (Afghanistan News Center 2008). According to a 2007 Department for International Development (DFID) (Galtung 2007) report, the crisis in the country is likely to continue for many years and may finally result in enormous failure with heavy casualties.

In this context of repeated failure by the security sector to deliver security - even after some security reform - there are bottom-up security institutions in the south-east of Afghanistan called Arbakai that are able to secure their areas, serving as a successful example of a grassrootsinitiated security institution. These institutions are effective, rooted in the society, and able to deliver security to communities and individuals.

\section{What is Arbakai?}

Pashtun tribes in the south-east of Afghanistan and bordering tribal areas live with their own security and justice systems. They created their own Arbakai, or tribally based policing and law enforcement system, grounded in volunteer grassroots initiatives. Arbakai is different from militias and those systems hired by private security companies that lack larger support and embeddedness. The latter are hired security groups deployed from the top-down by weak states in developing countries, and sometimes they are used for the benefit of powerful warlords, such as private companies in Afghanistan. Nor is Arbakai the same as statemade community policing, which is also a topdown system still characterised by passive relations between the community and police.

This article explores the details of the Arbakai as well as its leading institution, the Jirga, which also has judicial functions. In Pashto, Arbakai means 'messenger', and Arbakai has been defined in many ways by tribal leaders as well as other research scholars of Pashtunwali. As Ana Pejcinova (2007) says, 'Arbakai are institutions kindred to local police, consisting of respected community members who wear arms and protect the village'. A recently published report from the International Legal Foundation (ILF) about customary law in Afghanistan states that the enforcement system to implement final decisions of the Jirga is called Arbakai (ILF 2004).

One of the tribal leaders in the region interviewed by the author defined Arbakai as a group of volunteer adults - selected through a special procedure - who carry out the responsibilities to implement the Jirga's decisions, secure the territory of the tribe or the respected community and take action against those who perform illegal acts. Similar institutions to Arbakai exist in other areas but sometimes under a different name. For instance, in Federally Administered Tribal Areas (FATA), such institutions are called Salwishti and Shalgoon, and in Kandahar, they are called Paltanai.

Detailed responsibilities of Arbakai differ from one tribe to another. However, the major division of Arbakai duties are as follows:

- To implement the Jirga's decisions

- To maintain law and order

- To protect and defend borders and boundaries of the tribe or community.

All of these three general categories have various subcategories related to what is accepted as 
'common/public good or threat'. It is important to understand the concepts behind their power and the extent to which they are autonomous. However, imprisonment and the death penalty do not exist under the Pashtunwali code of conduct, nor does torture exist throughout the whole tribal system.

The concepts responsible for upholding Arbakai power are the following:

- Collectively accepted leadership of the institution called the Jirga

- Equally shared benefits and interests of all members of the tribe or the community

- Tribe or community members equally responsible for all financial obligations and expenses.

Building and strengthening trust and confidence is crucial to any system, whether or not they are state institutions. In the Arbakai, trust is built upon (1) practical impartiality of Arbakai;

(2) communal and/or tribal confidence in the leadership of Arbakai; and (3) the transparency of every aspects of Arbakai's work, which is public and open to all.

\section{Structure}

Based upon information from interviewees, Arbakai is a three-tier system that consists of three levels:

1 Tribe level

2 Sub-tribe level

3 Community level.

Arbakai institutions function in a decentralised way. Every level of Arbakai has its own leadership (Jirga) - with financial and administrative as well as decision-making power and autonomy including managerial aspects and geographically bounded areas. The decisions made by the Jirga are based on consensus and done 'deliberately' fitting categorisations of participatory governance (Fung and Wright 2003). The financial power of the Jirga is not limited to the collection of money but also includes expenditures. Financial responsibilities include logistical support to the Arbakai for tasks and duties, managing Machalga $a^{3}$ and insurance payment and distribution of achieved disputed properties, land, forests and other natural resources in the areas.
Figure 1 The organisational chart of Arbakai and Jirga institutions

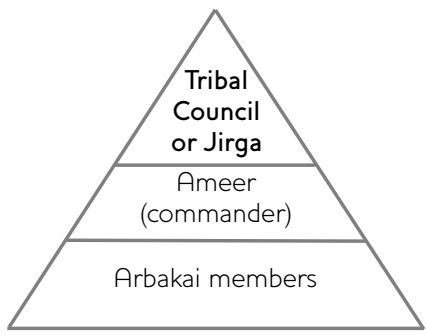

Note As mentioned, the number of Arbakai differs according to the levels and functions.

The Arbakai is responsible for implementing law and order based on the decisions of the Jirga. There is no way for a higher level Jirga to influence decisions made by lower level Jirga except through an appellate system or in cases when the lower level is not able to resolve a dispute. This happens when one of the parties of a conflict is not satisfied with the decision made by the Jirga. That person or party therefore has the right to appeal to the upper level Jirga to revisit the case. The same structure and power is mirrored by the Arbakai at the upper level in line with the Jirga.

\section{Organisational arrangement of Arbakai}

All three of the Arbakai's tiers have the same organisational arrangement with differences in the level of responsibilities, functions and numbers. The person who leads the Arbakai is called Ameer, an Arabic word meaning 'leader' or 'commander' (Figure 1). Usage of this word in the Arbakai system demonstrates the influence of Islamic culture on this system.

It is worth exploring the membership tribe or sub-tribe Jirga. One may think that everyone who is rich or whose ancestors were Jirga members will achieve membership. However, leadership and being a member of the Jirga is related to leadership skills and knowledge about the Pashtunwali codes and its judiciary system, no matter if a person is poor or rich, from a wellknown family or unknown family, or female or male. If someone claims that Jirga membership is inherited from fathers and grandfathers, it is most likely because family members, including sons and daughters who were serving the Jirga meetings, can sit and listen to the issues discussed by Jirga members, allowing them to 


\begin{tabular}{|c|c|c|c|c|}
\hline No. & Tribe name & $\begin{array}{l}\text { No. of Mirah } \\
\text { in } 1930\end{array}$ & $\begin{array}{l}\text { No. of Mirah } \\
\text { in } 2001\end{array}$ & No. of Nowkar \\
\hline 1 & Khost Centre & 48,000 & 170,000 & 12,000 \\
\hline 2 & Mangal & 48,000 & 170,000 & 12,000 \\
\hline 3 & Zadran & 36,000 & 135,000 & 9,000 \\
\hline 4 & Sabari & 12,000 & 45,000 & 3,000 \\
\hline 5 & Tanai & 12,000 & 45,000 & 3,000 \\
\hline 6 & Gurbuz & 4,000 & 15,000 & 1,000 \\
\hline
\end{tabular}

acquire knowledge and skills from such involvement. A famous example concerns one of the most qualified women, Maldara, in Khost. She has the highest rank of all Jirga members in the south-east region and her decisions cannot be challenged. There are other female Jirga members who are mostly from unknown families within their tribes. One cannot achieve membership at the highest level Jirga unless he/she acquires membership in the lowest level first. The number of Jirga members is proportionate to the number of families in the communities, sub-tribes and tribes. Every community has representatives in the sub-tribe Jirga and every sub-tribe has its own representatives in the tribal Jirga.

\section{Selection process of Arbakai}

First, the chief figure in the tribal system is Mirah (meaning 'man') but this is still related to the code of Pashtunwali where Mirah is not just a physically and biologically recognised man but also includes social and moral elements. Mirah means one who is honest, committed, and transparent in his/her life and brave enough not to act against those who are weak. There are specific figures of Mirahs in every big family, community, sub-tribe and tribe. There is another term inserted in Pashtunwali terminology, especially in the south-east, called Nowkar. This refers to the number of people from each tribe the central government called upon for military service in the early twentieth century. Since then the tribes have used it as a formula to determine their proportion of Arbakai. As can be seen in the tables, the number of Mirah is changeable but the Nowkar is unchanged since the 1930s. Table 1 shows the growing number of Mirah with a consistent number of Nowkar for some tribes in the south-east region.

Second, it needs to be determined how many Arbakai members will be needed for the task to be given to the Arbakai institution specified in the Jirga's decision. Once this number is clarified, the Arbakai will be counted proportionally to the whole population of Nowkars at every sub-level. For instance, the Tanai tribe, which is located in the border of Miranshah, the capital town of north Wazirestan, has four

Table 2 Selection of Arbakai for forest protection in the Tinai sub-tribe

\begin{tabular}{lcclc}
\hline $\begin{array}{l}\text { Name of } \\
\text { sub-tribe }\end{array}$ & No. of Mirah & No. of Nowkar & $\begin{array}{l}\text { Percentage of } \\
\text { sub-tribe Mirahs vs. } \\
\text { total Mirahs of tribe (\%) }\end{array}$ & $\begin{array}{l}\text { No. of Arbakai } \\
\text { members required }\end{array}$ \\
\hline Darnoohee & 22,500 & 1,500 & 50 & 40 \\
Sitkai & 7,500 & 500 & 16.6 & 13 \\
Aryozee & 7,500 & 500 & 16.6 & 13 \\
Khaabkhil & 7,500 & 500 & 16.6 & $\mathbf{8 0}$ \\
Total & $\mathbf{4 5 , 0 0 0}$ & $\mathbf{3 , 0 0 0}$ & $\mathbf{1 0 0}$ & \\
\hline
\end{tabular}

*This is rotated with two other sub-tribes in their future turns. 
sub-tribes. There is a dispute concerning the area of forest located in the mountains between those living on the other side of the border and the Tanai tribe. To protect and prove its ownership of the forest, the Tanai tribe decided to have 80 Arbakai continuously in the mountains to protect the forest. This number of Arbakai is calculated based on Nowkars numbered proportionately from four sub-tribes, keeping in mind that unlike the Mirah's number, the Nowkar number is constant and not changeable, as shown in Table 2.

The point to note is that every Mirah on the list currently exists, and every big family in which this system is rooted knows who is on the list. Systematically, those who are first on the list are the initial ones to be assigned for certain duties, such as protection of the forest in the case of the Tanai tribe, as briefly described above.

This selection method has a vital difference between the Arbakai and the Salwishti and Shalgoon institutions. However, the concepts are similar. In the Salwishti system the selection of Arbakai originates from the 40th of 40 (1/40) Mirahs and in the Shalgoon system the selection of the Arbakai originates from the 20th of 20 (1/20) Mirahs. Whether it is Salwishti or Shalgoon, the system is related to the number of Arbakai needed for one of the three general duties or any task specified by the Jirga, such as implementing a decision on a dispute.

\section{Operational procedure and functions}

To further understand the Arbakai, it will be helpful to discuss operational procedures and the functions related to the Arbakai. In principle, all three functions of the Arbakai described earlier (to implement the Jirga's decisions of the Jirgas; to maintain law and order and to protect the borders and boundaries of the tribe or community) are approved by the Jirga. The Jirgas are the highest policy and decision-making authority in the whole tribal system.

The operational procedure is different for any of these three types of functions and the Arbakai actions related to disputes have three types. First is prevention of disputes and conflicts, which is the law and order maintaining function; second is, during disputes and conflicts, to promote ceasefires between warring parties and to keep the Jirga informed of the situation. In this case, the
Arbakai is never authorised to act autonomously unless one of the warring parties does not accept the ceasefire. Those who ignore the Arbakai will face punishment and destruction of their homes.

After the Arbakai have secured the area, intervened between warring parties and informed the Jirga, it is then the responsibility of the Jirga to solve the dispute or conflict. To implement the Jirga's resolution of the conflict is the third function for the Arbakai. One principle for the Jirga in conflict and dispute resolution is quick decision-making and for the Arbakai to speedily implement decisions, except in murder cases, which require a slower process. The latter point is based on two reasons. First, the Arbakai want to investigate and collect more information to understand the real reasons of the incident; and second, Jirga members believe that being slow in the decision-making process can psychologically reduce the temper of the victimised party, making it possible for them to accept a logicbased solution rather than reacting emotionally.

After readiness of both sides to give Waak (unconditional power to make decisions on their behalf) to the Jirga, the Arbakai are asked for Machalga. If a party does not accept the decision, the money as Machalga will not be returned. Even if they appeal to a higher level Jirga, the lower level Jirga will be asked to explain the reasons behind its decision. If the higher level Jirga is satisfied with the decision, money will not be returned. Otherwise, the objection of higher level Jirga to the decision means that the money of Machalga will go to the higher level Jirga. After a decision has been made it passes to the implementation phase through the Arbakai, and their quick action is one of the most outstanding specifications that satisfies the victimised party and promotes trust in the Arbakai.

In short, it can be said that Arbakai are involved in three phases of any given conflict or dispute:

(1) pre-conflict through maintaining law and order and prevention of antisocial behaviour, (2) during conflict, and (3) after the Jirga's decision to solve the conflict.

In the case of territorial protection, the Arbakai has to constantly perform spot checks in different areas and patrol during both day and night. The Arbakai have strong support from the community members who feel they have a 
responsibility to help and assist them by informing them about something that may or they know will happen.

\section{Finance and expenditure}

Arbakai receives its financial support from the people through the Jirga, thus making the system accountable to the Jirga and the people. There are three financial sources that cover expenditures.

First, the Arbakai can acquire money collected by the Jirga on the basis of equal shares from the members of the community or tribe when there is an Arbakai mission planned. The amount of the money needed for such action is specified by the Jirga according to its devised plan. In financing Arbakai institutions, shares of the tribe's members are equal, whether the person is poor or rich. All members have to pay their own share so that the burden on any one individual is not too heavy. This equal share and payment system gives equal power to every member of the tribe to speak up when they feel the Jirga or Arbakai is headed in a mistaken direction. Such financial contribution from community and tribe members will require a type of strict accountability that is similar to the relation that exists between taxation and accountability (Joshi and Moore 2004).

Second, the Arbakai may use and spend the money received through fines collected as a result of punishment of a crime or antisocial behaviour. Machalga is another financial source in the case where one of the involved parties does not accept the Jirga's decision.

Third, the Jirga is equally obligated to collect money from the people when it needs to pay insurance to members threatened by one of three risks: death, disability and loss of beauty due to facial injuries. ${ }^{4}$

The financial sources mentioned have not only made Jirga and Arbakai institutions autonomous from the state, but they also made Arbakai accountable to the members of the tribe. The following section will concentrate on and explore the different aspects and mechanisms of accountability in Arbakai and Jirga systems.

\section{Downward and upward accountability mechanisms}

In the Arbakai system, there is both upward and downward accountability, which can guarantee the sustainability of the system and avoid corruption. Regarding upward accountability, Arbakai is accountable to the Jirga who lead and direct the Arbakai. The Jirga is a collective entity that may guarantee transparency inside the Jirga and can make it possible for Jirga members to supervise the implementation of various tasks by the Arbakai closely and carefully. There is clear division of responsibilities between Jirga as a decision-making body and Arbakai as an implementing institution. The Jirga management unit of Arbakai has the required autonomy to make decisions and give power to the Arbakai to implement the decisions. This clarity in responsibilities makes it easy for the Jirga and the people to track Arbakai and follow accountability mechanisms.

One can find many examples of the Jirga dismissing an Ameer or Arbakai due to inactivity or involvement in corruption. For instance, based on evidence from interviewees of the Tirizai tribe of Khost province, its Arbakai was asked to protect Mazarai ${ }^{5}$ until it was ripe for harvest. The Jirga received reports that the Ameer of the Arbakai was selling Mazarai when it was raw and green. The Jirga dismissed the Ameer after an eyewitness testimony, and he was blacklisted so he could never be appointed Ameer or Arbakai again.

There are also strong downward accountability mechanisms that make the Arbakai system trustworthy and sustainable. All three dimensions of accountability - as explained by Schedler (1999), 'dissemination of information, justification, and punishment' - are in place. The decisions made by the Jirga are public, and every member of the tribe and community is allowed to attend the Jirga's meetings. The tribe members also receive information through their representative in the Jirga about the decision made by the Jirga that the Arbakai will implement. With respect to the dimension of justification, every member of the tribe has the right to ask their leaders and representatives to justify their decisions. In the case where an Arbakai acts against decisions by the Jirga, the action will be rejected and those Arbakai members involved will be blacklisted.

There are two reasons for the strength of downward accountability mechanisms in the system. First, there are equal financial shares to 
be paid for Arbakai by all members of the tribe. This provides a way to improve quality of governance and to make citizens' engagement more effective in all politically and socially related matters through mutual obligations and common goods and interests (Moore and Schneider 2004: 47). The second reason is the equal social status of all members that does not discriminate with respect to wealth or social status, which is aided by the fact that no caste system exists within the region.

\section{The Arbakai and the state}

There is widespread discussion about how the Arbakai can address the failure of the security sector and incorporate more people into the process. Some believe, such as Sedra (2004: 17-18), that it is necessary to integrate Arbakai into the state security apparatus. However, Sedra exaggerates the reality of the situation, insisting on full integration within the security sector. There is a danger of integrating such a successful system with the failed security sector he describes. He did not take into account the history of Arbakai's institutions and their creation, which preceded the nation-state. Furthermore, Arbakai follows Pashtuns' customary law, while the state police follow civil law. According to one tribal leader, 'Governments are coming and going but our system is the same, they cannot change our system' (Heinrich Boll Foundation 2006).

\section{Conclusion}

Based on the observations in this article, insecurity is of growing concern in Afghanistan. It is not rational to expect and wish stability and security from a state with weak institutions; a failed security sector; the problematic presence of international forces such as the USA (Luckham 2004) and high corruption in service and aid-providing entities. In a situation of conflict and state crisis, the Arbakai are playing an alternative role to provide security for the people in the south-east region of the country without posing a serious financial burden on the people.

Based on this argument, it is clear that Arbakai institutions are profoundly rooted in democracy and have empowered participatory governance (Fung and Wright 2003). Some of the key principles and elements concerning observations of the Arbakai are as follows:

- active and collective participation of tribes' members in Arbakai institutions

- social embeddedness based on social cohesion as key to supporting collective leadership, thus creating strong accountability mechanisms

- merit-based nomination or election of Jirga members as a leading institution to the Arbakai

- managerial and geographical decentralisation adopted by three levels of Jirga and Arbakai institutions

- strong mechanisms of upward and downward accountability, based on three concepts: (1) publicity of information, (2) justification, and (3) punishment and enforcement in the case of broken rules and regulations

- bottom-up approaches give full ownership to the people, which cannot be achieved in topdown programmes

- clear division of responsibilities between the Jirga as the autonomous decision-making body and Arbakai as the implementing institution

- equal power based on equal financial contribution of all members of the tribe

- strong contextual and conceptual foundations

- proven to be a sustainable institution passing through different periods of internal conflict and external intervention.

According to the discussion above, it is possible to engage the Jirga and Arbakai with the state, as they are co-governance institutions. However, it would be impractical and increasingly challenging to integrate them completely into the failed state apparatus. 


\section{Notes}

1 Part of earning trust and building a true national institution is ensuring that the population is reflected in the make-up of the command and control structures. Both ethnic and gender imbalances also need to be addressed urgently (ICG 2007).

2 Chris Sands, 'Bring Back Taliban to End Police Corruption, say Afghan Truckers', Independent, 10 May 2007. 'We pay all our bribes to criminals, and they are criminals who wear police uniforms', said truck driver Abad Khan. 'Cargo Transporters go on Strike Today: Truck Owners Threaten to Stop Supplies to NATO Troops', Daily Times, 27 April 2007; 'Truckers Stop Supplies to NATO in Afghanistan', The News, 28 April 2007 (ICG 2007: 16).

\section{References}

Afghanan Dot Net (2007) Pashtunwali - Terms, www.afghanan.net/pashto/pashtunwali/terms. htm (accessed 27 August 2007)

Afghanistan News Center (2008) Afghanistan's

Karzai Angry over US Killings, www.afghanistannewscenter.com/news/2008/ november/nov102008.html\#1 (accessed 10 November 2008)

Beaumont, Peter (2007) 'War Zone Aid Fuels More Conflict', The Observer 14 January, London, http://observer.guardian.co.uk/world/story/ 0,,1990041,00.html (accessed 18 July 2007)

Fung, A. and Wright, D. (eds) (2003) Deepening Democracy: Institutional Innovations in Empowered Participatory Governance, London: Verso

Galtung, J. (2007) 'Development Dilemmas: Challenges of Working in Conflict Situations in South Asia', Development Dilemmas: Challenges of Working in Conflict situations in South Asia, 5-6 March, London: Department for International Development (DFID)

Giustozzi, A. (2007) 'Auxiliary Force or National Army? Afghanistan's "ANA" and the Counterinsurgency Effort, 2002-2006', Journal of Small Wars and Insurgencies 18.1: 45-67

Heinrich Boll Foundation (2006) Spingiri the White Beards (video), Berlin: HBF, CD-Rom

ICG (International Crisis Group) (2007) Reforming Afghanistan's Police, Asia Report 138, www.crisisgroup.org/library/documents/asia/ south_asia/138_reforming_afghanistan_s_ police.pdf (accessed 30 August 2007)
3 Machalga is the surety given to the marakachyan (Jirga members) by both sides of the case in dispute, ensuring unconditional compliance of the maraka's decision. The Machalga is forfeited against the side not accepting the maraka sentence. Unless the Machalga is given, the maraka will not be convened. When convened, the maraka will ask both sides to pledge orally that the side not accepting the decision will not request return of its Machalga (Afghanan Dot Net 2007).

4 A committee observes then presents their findings to the Jirga, which assesses the value of the damage and the appropriate amount of money is given to the injured person.

5 A special plant growing in south-east Afghanistan which is used to make beds called katt, hats, ropes, etc.

ILF (International Legal Foundation) (2004) The Customary Laws of Afghanistan, www.usip.org/ ruleoflaw/projects/ilf_customary_law_ afghanistan.pdf (accessed 15 February 2007)

Joshi, A. and Moore, M. (2004) 'Institutionalised Co-production: Unorthodox Public Service Delivery in Challenging Environments', Journal of Development Studies 40.4: 31-49

Luckham, Robin (2004) 'The International Community and State Reconstruction in Wartorn Societies', Journal of Conflict, Security and Development 4.3: 481-507

Moore, M. and Schneider, A. (2004) Taxation, Governance and Poverty: Where Do the Middle Income Countries Fit?, IDS Working Paper 230, Brighton: IDS

Pejcinova, Ana (2007) Afghanistan: Creation of a Warlord Democracy - The Afghan Cultural Model, www.volny.cz/apejcinova/Theses/Afghanistan/ 9ch3.htm (accessed 15 February 2007)

Schedler, A. (1999) 'Conceptualising Accountability', in Andreas Schedler, Larry Diamond and Marc F. Plattner (eds), The SelfRestraining State: Power and Accountability in New Democracies, London: Lynne Reinner

Sedra, M. (2004) 'Consolidating an Elusive Peace: Security Sector Reform in Afghanistan', in A. Bryden and H. Hänggi (eds), Reform and Reconstruction of the Security Sector, Geneva: Geneva Centre for the Democratic Control of Armed Forces: 207-29 